\title{
Rancang Bangun Gelang Locator Pasien Terkonfirmasi Covid-19 dengan Metode Haversine sebagai Pengidentifikasian Pelanggaran Zona Aman Isolasi Mandiri Menggunakan Komunikasi Lora (Long Range)
}

\author{
Ahmad Afan Maulana'), Riza Alfita ${ }^{2)}$, dan Achmad Fiqhi Ibadillah ${ }^{3)}$ \\ 1,2,3) Jurusan Teknik Elektro, Fakultas Teknik, Universitas Trunojoyo Madura \\ 1,2,3) J1. Raya Telang, Perumahan Telang Indah, kamal, Kabupaten Bangkalan, Jawa Timur \\ e-mail: maulana07@live.com ${ }^{1)}$, riza.alfitatrunojoyo@gmail.com ${ }^{2)}$, fiqhi.ibadillah@ $\underline{\text { trunojoyo.ac.id }}^{3)}$
}

\begin{abstract}
Positive cases of COVID-19 continue to grow rapidly. This prompted the government to make new rules in the form of various types of health protocols. One of them is the implementation of the self-isolation protocol for confirmed COVID-19 patients. Self-isolation is a rule that requires confirmed patients to stay at home until the specified time limit to break the chain of COVID-19 development. However, it is suggested and as a rule that there are still many ODP and PDP who still violate the rules of self-isolation from the government. The ODP and PDP still roam freely without thinking about the impacts and risks to their surroundings. With the departure of confirmed patients, the risk of developing COVID-19 becomes greater. In this study, a confirmed patient locator bracelet was made that can map the position of the patient based on latitude and longitude. The latitude and longitude data from the bracelet is sent to the gateway by LoRa communication. LoRa communication is also used to minimize the dimensions of the bracelet. In addition to mapping the location of the patients, by applying the Heversine method this system is able to identify when a safe zone violation occurs in the form of a change in the color of the marker. In the future, it is hoped that this system will be able to handle the problem of developing COVID-19 caused by confirmed patients who still violate the self-isolation protocol.
\end{abstract}

Keywords: API, COVID 19, Heversine, LoraWAN, Internet of Things

\begin{abstract}
ABSTRAK
Kasus positif COVID-19 terus saja berkembang pesat. Hal ini mendorong pemerintah untuk membuat aturan baru berupa protokol-protokol kesehatan yang berbagai macam jenisnya. Salah satunya ialah penerapan protokol isolasi mandiri yang diperuntukkan bagi para pasien terkonfirmasi COVID-19. Isolasi mandiri ialah aturan yang mewajibkan para pasien terkonfirmasi untuk tetap di rumah sampai batas waktu yang ditentukan untuk memutus rantai perkembangan COVID-19. Namun dihimbau dan menjadi aturan masih banyak para ODP dan PDP yang tetap saja melanggar aturan isolasi mandiri dari pemerintah. Para ODP dan PDP tetap saja berkeliaran bebas tanpa memikirkan dampak dan resiko terhadap sekitarnya. Dengan berkeliarnya para pasien terkonfirmasi maka resiko perkembangan COVID-19 menjadi besar. Pada penelitian ini dibuat gelang locator pasien terkonfirmasi yang dapat memetakan posisi para pasien berdasarkan latitude dan longitude. Data latitude dan longitude dari gelang dikirimkan ke gateway dengan komunikasi LoRa. Komunikasi LoRa dipakai juga untuk meminimalisir dimensi dari gelang. Selain memetakan lokasi para pasien, dengan menerapkan metode Heversine system ini mampu mengidentifikasi bila terjadi pelanggaran zona aman berupa perubahan warna marker. Kedepannya diharapkan system ini mampu mengani masalah perkembangan COVID-19 yang disebabkan oleh para pasien terkonfirmasi yang masih banyak melanggar protokol isolasi mandiri.
\end{abstract}

Kata kunci: API, COVID 19, Heversine, LoraWAN, Internet of Things.

\section{Pendahuluan}

$\mathrm{C}$ OVID-19 adalah wabah virus yang menjadi pandemik di seluruh dunia saat ini termasuk Indonesia. Berdasarkan statistik perkembangan covid per tanggal 11 Januari 2021 laju perkembangan pasien terkonfirmasi di Indonesia mencapai 828,026 pasien, dengan cluster penyebaran terbanyak terjadi di Provinsi Jakarta dan Jawa Timur. Bila dilihat dari statistik keseluruhan perkembangan COVID-19 di Indonesia yang dimulai dari awal Maret hingga September, perkembangan COVID-19 di Indonesia meningkat secara signifikan yang mana puncaknya terjadi pada tanggal 9 Januari 2021 yaitu sebanyak 10.617 pasien terkonfirmasi per harinya. Akibat dari hal ini pemerintah menerapkan Pembatasan Sosial Berskala
Besar atau yang familiar disebut PSBB. Hal ini sebagai upaya pemerintah untuk memutus mata rantai perkembangan COVID-19 di Indonesia. Dimulai awal Maret hingga awal Juni 2020 dilaksanakan PSBB di seluruh Indonesia. Namun tetap saja perkembangan COVID-19 di Indonesia masih saja terjadi peningkatan secara signifikan. Ini dikarenakan masih banyak masyarakat yang melanggar peraturan PSSBB dan masih banyak pasien terkonfirmasi yang berkeliaran keluar rumah.

Karena dalam penyebarannya COVID-19 tergolong mudah yaitu hanya melalui droplet atau percikan yang keluar dari hidung atau mulut dan menempel di benda seperti tangga, meja, dan sarana umum lainnya. Maka semakin banyak orang berkerumun atau berkumpul dalam suatu tempat maka semakin besar pula resiko 
COVID-19 tersebar. Terutama bila di antara orang tersebut terdapat pasien terkonfirmasi COVID-19.

Sebenarnya permasalahan pertama dari pandemi ini ialah para pasien terkonfirmasi yang masih saja ada yang tidak mematuhi aturan dari pemerintah. Menyikapi ini pemerintah memberlakukan isolasi bagi para pasien terkonfirmasi di rumah sakit sebagai solusi agar pasien bisa dipantau dan ditertibkan. Namun masalah lain muncul akibat kebijakan tersebut, banyak rumah sakit mengalami overload ruang isolasi. Hal ini berimbas pada sarana dan prasarana public yang dialih fungsikan menjadi rumah sakit darurat untuk menampung pasien terkonfirmasi. Sebut saja wisma atlet yang sejak awal sudah dijadikan rumah sakit darurat oleh pemerintah dan masih banyak lagi sarana dan prasarana public yang beralih fungsi menjadi rumah sakit darurat.

Melihat masalah ini saya membuat penelitian yang berjudul Rancang Bangun Gelang Locator Pasien Terkonfirmasi COVID-19 Dengan Metode Heversine sebagai Pengidentifikasian Pelanggaran Zona Aman Isolasi Mandiri Menggunakan Komunikasi LoRa (Long Range) . Cara kerja dari system ini sendiri ialah dengan mengirimkan koordinat pasien dengan menggunakan alat berupa gelang. Koordinat tersebut digunakan sebagai parameter untuk selanjutnya dikalkulasikan dengan koordinat zona aman yang telah ditentukan di awal. Selanjutnya dilakukan pengidentifikasian apakah pasien tersebut melanggar protokol isolasi mandiri atau tidak. Diharapkan dengan adanya penelitian ini, perkembangan COVID-19 di Indonesia bisa ditekan seminimal mungkin.

\section{A.COVID 19}

\section{TEORI}

COVID-19 adalah virus pertama ditemukan di Wuhan, China pada tahun 2019. Organisasi Kesehatan Dunia secara resmi menamai penyakit yang disebabkan oleh novel coronavirus sebagai penyakit coronavirus 2019 (COVID-19). Gejala awal yang dirasakan oleh penderita ialah seperti gejala flu seperti biasa sehingga banyak dari pemimpin Negara beranggapan bahwa virus ini tidak berbeda jauh dengan virus biasa. Namun gejala serius ditemukan dalam kurun waktu 14 hari terjangkit, gejala yang banyak muncul ialah demam, batuk sampai dengan sesak nafas bahkan ada beberapa dari penderita yang meninggal dunia.

\section{B. LoRa (Long Range)}

LoRa merupakan salah satu protocol komunikasi nirkabel jarak jauh dan berdaya rendah. LoRa menjadi solusi baru untuk pengaplikasian Internet of Things yang membutuhkan infrastruktur minimal dengan hasil yang maksimal. LoRa memiliki dukungan langsung dari beberapa perusahaan teknologi diantaranya ialah IBM, Semtech, Actility, dll yang merupakan Aliansi dari LoRa Allience.LoRa beroperasi di pita frekuensi 923,
868 atau 915, 920, $923 \mathrm{MHz}$, tergantung kebijakan setiap wilayah. Di Indonesia sendiri kominfo menetapkan frekuensi untuk penggunaan LoRa di Indonesia ialah di rentan frekuensi $915-923 \mathrm{MHz}$ [1].

\section{LoRaWAN}

LoRaWAN merupakan mekanisme kontrol akses menengah, yang memungkinkan banyak perangkat untuk berkomunikasi dengan gateway menggunakan modulasi LoRa. Secara umum, LoRaWAN adalah protokol yang digunakan untuk mengirimkan data dari beberapa node atau sensor menuju network server menggunakan protokol LoRa. Dari perspektif pengembangan aplikasinyam jaringan LoRaWAN sangat cocok untuk digunakan dalam pengaplikasian IoT (Internet of Things) [2].

\section{GPS (Global Position System)}

GPS adalah system navigasi yang digunakan untuk mengetahui detail suatu tempat atau informasi dengan cepat, tepat da akurat berdasarkan data yang diterima dari satelit. GPS biasanya diaplikasikan dalam beberapa system, namun yang paling popular yaitu system trackng dimana gps akan mengirimkan data berupa latitude dan longitu untuk mengetahui posisi [7].

\section{E. API (Application Programming Interface)}

API adalah seperangkat antarmuka pemrograman apliaksi yang dapat digunakan untuk mengembangkan aplikasi dalam satu platform ataupun lintas platform. API dapat berupa kumpulan method dan class dari suatu pustaka yang dinamakan Pustaka API. Secara garis besar API terbagi menjadi 3 kategori yaitu. [8] : Ownership WEB API, Communication Level API, WEB Service API.

\section{F. Metode Heversine}

Metode Haversine adalah metode yang digunakan untuk melakukan kalkulasi jarak antara dua titik kordinat dalam sebuah area.

\section{METODE}

Perancangan system ini menggunakan 2 tahap perancangan, yaitu perancangan perangkat keras (hardware) dan perancangan perangkat lunak (software).

\section{A. Hardware}

Dalam pembuatannya terdapat beberapa komponen yang digunakan sebagai penunjang pembuatan system, diantaranya yaitu: ESP32, esp 8266, gps neo blox 6, strap, sx1276, antenna 923Mhz, tiang bambu, box. Semua komponen disusun sesuai tahapan sehingga system bisa bekerja dengan baik. 


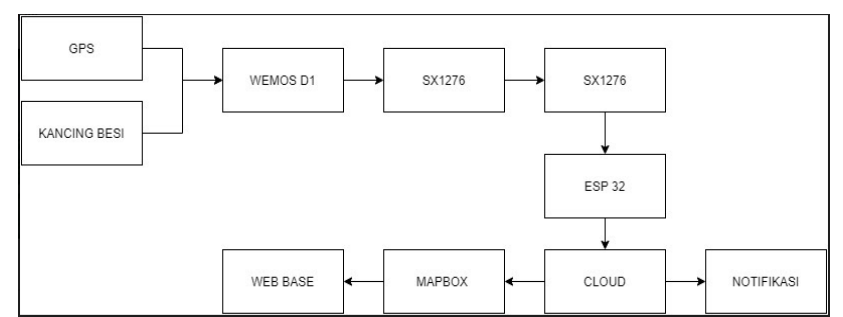

Gambar 1. Diagram koneksi hardware

Pada diagram diatas terdapat 1 iput yaitu gps, gps mengirimkan latitude dan longitude menggunakan sx1276 sebagai LoRa transceiver ke ESP32 yang diterima dengan sx1276 sebagai LoRa receiver. Selanjutnya latitude dan longitude dikirim menuju cloud yang selanjutnya di parsing untuk selanjutnya ditampilkan di WEB menggunakan API Mapbox.

1. Node

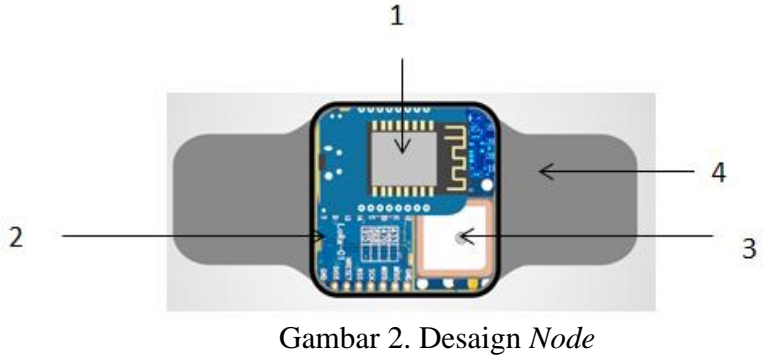

Berikut adalah penjelasan dan fungsi dari nomor di desaign alat di atas

1. ESP8266 berfungsi sebagai mikrokontroller dan node suntuk mentransmisikan data. Pemilihan ESP8266 dikarenakan esp8266 memiliki regulator $3,3 \mathrm{v}$ untuk mensupply sx1276 agar tidak terjadi over voltage serta karena dmensi ESP8266 memiliki dimensi yang memungkinkan diposisikan diatas dua komponen lainnya.

2. SX1276 berfungsi sebagai antenna yang digunakan sebagai transmisi data GPS ke gateway.

3. GPS Neo Blox-6 berfungsi sebagai pemberi kordinat latitude dan longitude.

4. Strap karet berfungsi sebagai gelang agar alat nyaman dipakai koordinat lubang pcb yang telah di tentukan. Raspberry juga terhubung dengan limit switch yang berfungsi untuk memberi batasan pada motor stepper agar tidak bekerja melewati bidang kerja yang telah ditentukan.

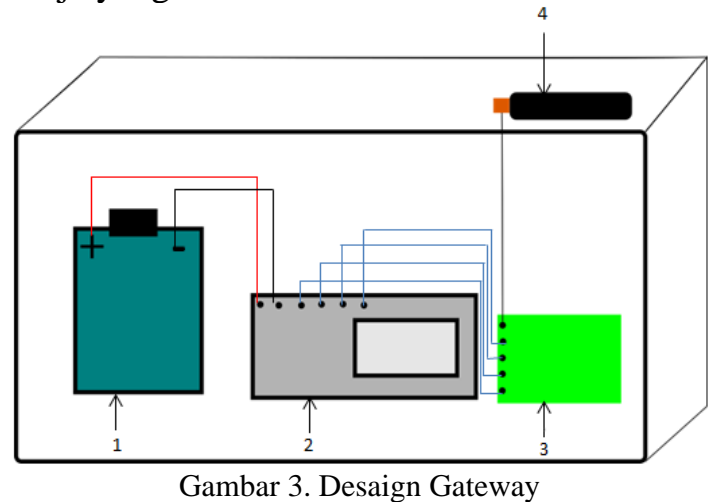

Berikut merupakan penjelasan dari masing-masing komponen di atas

1. Baterai berfungsi sebagai supply ESP32.

2. ESP32 digunakan untuk mengirimkan data latitude dan longitude yang diterima dari beberapa node menuju server atau cloud.

3. Sx1276 digunakan sebagai antena receiver untuk menerima data ang di transmisikan oleh beberapa node.

4. Antenna $915 \mathrm{MHz}$ digunakan sebagai penguat gelombang agar gateway dapat menerima beberapa transmisi data sekaligus dengan lancar.

\section{B. Software}

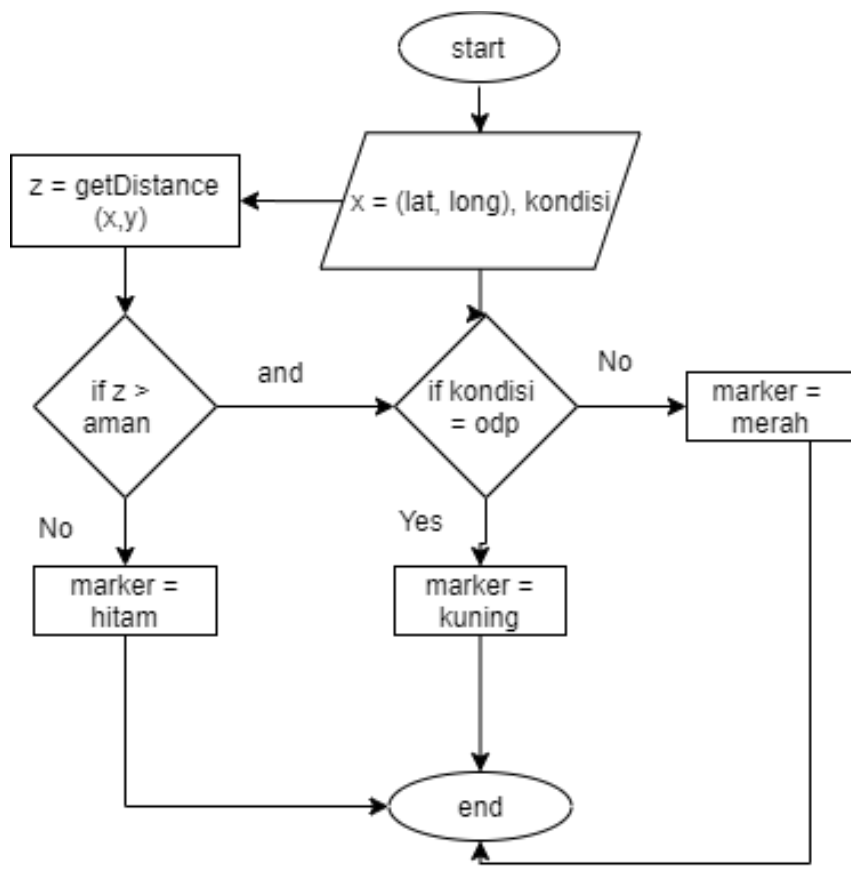

Gambar 4. Flowchart Software

Program dimulai dengan mengambi data dari cloud dan database. Untuk data dari cloud yang diambil ialah latitude dan longitude disini saya beri nama y. dan data yang diambil dari database yaitu latitude, longitude dan kondisi, latitude dan longitude dari database diberi nama $\mathrm{x}, \mathrm{x}$ adalah koordinat radius aman pasien sedangkan y ialah koordinat real-time yang didapat dari gps. Selanjutnya $\mathrm{x}$ dan y dikalkulasi menggunakan metode heversine untuk diketahui selisih jarak antara $\mathrm{x}$ dan y. Jika jarak hasil kalkulasi melebihi jarak aman maka marker akan berubah menjadi hitam, namun jika jarak masih berada dalam jarak aman maka marker akan bewarna sesuai dengan kondisi pasien, untuk ODP bewarna kuning dan PDP bewarna merah.

\section{HASIL DAN PEMBAHASAN}

Hasil dari penelitian ini ialah gelang yang mampu mengirimkan data latitude dan longitude untuk selanjutnya dijadikan parameter untuk 
mengindentifikasi pelanggaran zona aman oleh para pasien terkonfirmasi covid 19. Komponen utama dari alat ini iaah node dan gateway. Adapun ada beberapa tahapan pengujian yang dilakukan untuk mencapai keberhasilan alat yang diinginkan.

\section{A. Transmit Data Node}

Pada percobaan pertama di lakukan pengiriman data dari node. Data yang dikirimkan berupa latitude, longitude yang berasal dari modul GPS neo 6 serta data tegangan kancing yang dihubungkan dengan pin D1 Wemos. Node yang digunakan disini sebanyak 3 node dengan spesifikasi yang sama untuk melihat sampai sejauh mana jarak yang dapat di receive oleh gateway dari ketiga node tersebut. Skema pengujian terbagi menjadi 3, yaitu dengan 1 node, 2 node dan yang .terakhir 3 node. Hal ini untuk menguji respon gateway terhadap jumlah node yang di transmisikan.

Tabel I. Data hasil pengukuran jarak dengan 1 transmisi dari node 1. Node

\begin{tabular}{lllll} 
ID & Waktu & Latitude & longitude & Jarak \\
\hline 001 & 14.53 .20 & -7.048762 & 113.934385 & $0 \mathrm{~m}$ \\
\hline 001 & 14.56 .50 & -7.0469967 & 113.9300747 & $800 \mathrm{~m}$ \\
\hline 001 & 14.59 .10 & -7.043621 & $113 . .923277$ & $1.5 \mathrm{~km}$ \\
\hline 001 & 15.03 .40 & -7.0371341 & 113.9104658 & $3.1 \mathrm{~km}$ \\
\hline 001 & 15.06 .13 & -7.033686 & 113.907752 & $3.9 \mathrm{~km}$ \\
\hline 001 & 15.10 .30 & -7.0389739 & 113.9001919 & $4.4 \mathrm{~km}$ \\
\hline 001 & 15.14 .50 & -7.032920 & 113.890290 & $5.7 \mathrm{~km}$ \\
\hline 001 & 15.17 .08 & -7.028128 & 113.881482 & $6.9 \mathrm{~km}$ \\
\hline 001 & 14.20 .57 & -7.017139 & 113.879313 & $8.1 \mathrm{~km}$ \\
\hline 001 & 14.25 .01 & -7.005676 & 113.861654 & $10.3 \mathrm{~km}$
\end{tabular}

Tabel II. Data hasil pengukuran transmit data dengan 2 node

\begin{tabular}{lllll} 
ID & Waktu & Latitude & Longitude & Jarak \\
\hline 001 & 14.53 .20 & -7.048762 & 113.934385 & $0 \mathrm{~m}$ \\
\hline 002 & 14.56 .50 & -7.0469967 & 113.9300747 & $800 \mathrm{~m}$ \\
\hline 001 & 14.59 .10 & -7.043621 & $113 . .923277$ & $1.5 \mathrm{~km}$ \\
\hline 002 & 15.03 .40 & -7.0371341 & 113.9104658 & $3.1 \mathrm{~km}$ \\
\hline 001 & 15.06 .13 & -7.033686 & 113.907752 & $3.9 \mathrm{~km}$ \\
\hline 002 & 15.10 .30 & -7.0389739 & 113.9001919 & $4.4 \mathrm{~km}$ \\
\hline 001 & 15.14 .50 & -7.032920 & 113.890290 & $5.7 \mathrm{~km}$ \\
\hline 002 & 15.17 .08 & -7.028128 & 113.881482 & $6.9 \mathrm{~km}$ \\
\hline 001 & 14.20 .57 & -7.017139 & 113.879313 & $8.1 \mathrm{~km}$ \\
\hline 002 & 14.25 .01 & -7.005676 & 113.861654 & $10.3 \mathrm{~km}$
\end{tabular}

Tabel III. Data hasil pengukuran transmit data dengan 2 node

\begin{tabular}{lllll} 
ID & Waktu & Latitude & Longitude & Jarak \\
\hline 001 & 14.53 .20 & -7.048762 & 113.934385 & $0 \mathrm{~m}$ \\
\hline 002 & 14.56 .50 & -7.0469967 & 113.9300747 & $800 \mathrm{~m}$ \\
\hline 003 & 14.59 .10 & -7.043621 & $113 . .923277$ & $1.5 \mathrm{~km}$ \\
\hline 001 & 15.03 .40 & -7.0371341 & 113.9104658 & $3.1 \mathrm{~km}$ \\
\hline 002 & 15.06 .13 & -7.033686 & 113.907752 & $3.9 \mathrm{~km}$ \\
\hline 003 & 15.10 .30 & -7.0389739 & 113.9001919 & $4.4 \mathrm{~km}$ \\
\hline 001 & 15.14 .50 & -7.032920 & 113.890290 & $5.7 \mathrm{~km}$ \\
\hline 002 & 15.17 .08 & -7.028128 & 113.881482 & $6.9 \mathrm{~km}$ \\
\hline 003 & 14.20 .57 & -7.017139 & 113.879313 & $8.1 \mathrm{~km}$ \\
\hline 003 & 14.25 .01 & -7.005676 & 113.861654 & $10.3 \mathrm{~km}$
\end{tabular}

\section{B.Receive Data Gateway}

Setelah data di transmit oleh ketiga node, selanjutnya data akan diterima oleh gateway dan di direct ke google cloud firebase utnuk selanjutnya di kelola di backend dan ditampilkan di frontend. Dalam pengujian kali ini gateway diletakkan di rumah dengan ketinggian sekitar 7 meter diatas permukaan tanah. Frekuensi yang digunakan oleh gateway dan node sama-sama menggunakan alokasi frequensi di 923 MHz. Setiap node mempunyai id unik tersendiri untuk membedakan antara node 1 dengan node lainnya. Berikut adalah tabel hasil dari penerimaan data dari ketiga node tersebut :

Tabel IV. Data hasil receive dengan 1 node

\begin{tabular}{|c|c|c|c|c|c|c|c|}
\hline ID & $\begin{array}{l}\text { Wak } \\
\text { tu }\end{array}$ & $\begin{array}{l}\text { Latitud } \\
\text { e }\end{array}$ & $\begin{array}{l}\text { Longitu } \\
\text { de }\end{array}$ & Jarak & $\begin{array}{l}\text { RS } \\
\text { SI }\end{array}$ & $\begin{array}{l}\text { Dela } \\
\mathrm{y}\end{array}$ & $\begin{array}{l}\text { Late } \\
\text { ncy }\end{array}$ \\
\hline $\begin{array}{l}00 \\
1\end{array}$ & $\begin{array}{l}14.5 \\
3.20\end{array}$ & $\begin{array}{l}- \\
7.0487 \\
62\end{array}$ & $\begin{array}{l}113.93 \\
4385\end{array}$ & $0 \mathrm{~m}$ & -48 & $1 \mathrm{~s}$ & $0 \mathrm{~ms}$ \\
\hline $\begin{array}{l}00 \\
1\end{array}$ & $\begin{array}{l}14.5 \\
6.50\end{array}$ & $\begin{array}{l} \\
7.0469 \\
967\end{array}$ & $\begin{array}{l}113.93 \\
00747\end{array}$ & $800 \mathrm{~m}$ & $\overline{47}$ & $1 \mathrm{~s}$ & $0 \mathrm{~ms}$ \\
\hline $\begin{array}{l}00 \\
1\end{array}$ & $\begin{array}{l}14.5 \\
9.10\end{array}$ & $\begin{array}{l}- \\
7.0436 \\
21\end{array}$ & $\begin{array}{l}113 . .92 \\
3277\end{array}$ & $\begin{array}{l}1.5 \mathrm{k} \\
\mathrm{m}\end{array}$ & $-\overline{49}$ & $1 \mathrm{~s}$ & $0 \mathrm{~ms}$ \\
\hline $\begin{array}{l}00 \\
1\end{array}$ & $\begin{array}{l}15.0 \\
3.40\end{array}$ & $\begin{array}{l}7.0371 \\
341\end{array}$ & $\begin{array}{l}113.91 \\
04658\end{array}$ & $\begin{array}{l}3.1 \mathrm{k} \\
\mathrm{m}\end{array}$ & 54 & $1 \mathrm{~s}$ & $0 \mathrm{~ms}$ \\
\hline $\begin{array}{l}00 \\
1\end{array}$ & $\begin{array}{l}15.0 \\
6.13\end{array}$ & $\begin{array}{l}7.0336 \\
86\end{array}$ & $\begin{array}{l}113.90 \\
7752\end{array}$ & $\begin{array}{l}3.9 \mathrm{k} \\
\mathrm{m}\end{array}$ & 50 & $1 \mathrm{~s}$ & $0 \mathrm{~ms}$ \\
\hline $\begin{array}{l}00 \\
1\end{array}$ & $\begin{array}{l}15.1 \\
0.30\end{array}$ & $\begin{array}{l}7.0553 \\
12\end{array}$ & $\begin{array}{l}113.90 \\
9723\end{array}$ & $\begin{array}{l}4.4 \mathrm{k} \\
\mathrm{m}\end{array}$ & 50 & $1 \mathrm{~s}$ & $0 \mathrm{~ms}$ \\
\hline $\begin{array}{l}00 \\
1\end{array}$ & $\begin{array}{l}15.1 \\
4.50\end{array}$ & $\begin{array}{l}7.0507 \\
34\end{array}$ & $\begin{array}{l}113.09 \\
327\end{array}$ & $\begin{array}{l}5.7 \mathrm{k} \\
\mathrm{m}\end{array}$ & $\overline{51}$ & $1 \mathrm{~s}$ & $\begin{array}{l}20 \mathrm{~m} \\
\mathrm{~s}\end{array}$ \\
\hline $\begin{array}{l}00 \\
1\end{array}$ & $\begin{array}{l}15.1 \\
7.08\end{array}$ & $\begin{array}{l}\overline{7} \\
7.0337 \\
5 \% \# \$\end{array}$ & $\begin{array}{l}113.9 * \\
* \&\end{array}$ & $\begin{array}{l}6.9 \mathrm{k} \\
\mathrm{m}\end{array}$ & $\overline{60}$ & $1 \mathrm{~s}$ & $\begin{array}{l}200 \\
\mathrm{~ms}\end{array}$ \\
\hline $\begin{array}{l}00 \\
1 \\
\end{array}$ & $\begin{array}{l}14.2 \\
0.57 \\
\end{array}$ & -7.050 & $\begin{array}{l}113.09 \\
9827\end{array}$ & $\begin{array}{l}8.1 \mathrm{k} \\
\mathrm{m}\end{array}$ & $-\overline{63}$ & $1 \mathrm{~s}$ & $\begin{array}{l}500 \\
\mathrm{~ms}\end{array}$ \\
\hline $\begin{array}{l}00 \\
1\end{array}$ & $\begin{array}{l}14.2 \\
5.01\end{array}$ & 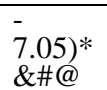 & $\begin{array}{l}113.9 \% \\
\# * 3\end{array}$ & $\begin{array}{l}10.3 \mathrm{k} \\
\mathrm{m}\end{array}$ & $-\overline{62}$ & $1 \mathrm{~s}$ & $\begin{array}{l}500 \\
\mathrm{~ms}\end{array}$ \\
\hline
\end{tabular}

Tabel VI. Data hasil pengukuran sumbu y- sejauh $5 \mathrm{~mm}$ Hasil pengukuran $\quad$ Akurasi (\%) $\quad$ Error (\%)

\begin{tabular}{ccc}
$(\mathrm{mm})$ & & \\
\hline 5.2 & 98 & 2,00 \\
\hline 5.5 & 95 & 5,00 \\
\hline 5.2 & 98 & 2,00 \\
\hline 5 & 100 & 0,00 \\
\hline 5 & 100 & 0,00 \\
\hline 5.1 & 99 & 1,00 \\
\hline 4.7 & 97 & 3,00 \\
\hline 4.9 & 99 & 1,00 \\
\hline 5.1 & 99 & 1,00 \\
\hline 5.2 & 98 & 2,00 \\
\hline & Rata-rata & 1,7 \\
\hline \hline
\end{tabular}

Tabel V. Data hasil receive dengan 2 node

\begin{tabular}{|l|l|l|l|l|l|l|l|}
\hline ID & $\begin{array}{l}\text { Wak } \\
\text { tu }\end{array}$ & $\begin{array}{l}\text { Latitud } \\
\mathrm{e}\end{array}$ & $\begin{array}{l}\text { Longitu } \\
\mathrm{de}\end{array}$ & $\begin{array}{l}\text { Jara } \\
\mathrm{k}\end{array}$ & $\begin{array}{l}\text { RS } \\
\text { SI }\end{array}$ & $\begin{array}{l}\text { Del } \\
\text { ay }\end{array}$ & $\begin{array}{l}\text { Late } \\
\text { ncy }\end{array}$ \\
\hline $\begin{array}{l}00 \\
1\end{array}$ & $\begin{array}{l}14.5 \\
3.20\end{array}$ & $\begin{array}{l}- \\
7.0487 \\
62\end{array}$ & $\begin{array}{l}113.934 \\
385\end{array}$ & $0 \mathrm{~m}$ & -54 & $1 \mathrm{~s}$ & $0 \mathrm{~ms}$ \\
\hline 00 & $\begin{array}{l}14.5 \\
6.50\end{array}$ & $\begin{array}{l}- \\
7.0469 \\
967\end{array}$ & $\begin{array}{l}113.930 \\
0747\end{array}$ & $\begin{array}{l}800 \\
\mathrm{~m}\end{array}$ & -50 & $1 \mathrm{~s}$ & $0 \mathrm{~ms}$ \\
\hline 00 & 14.5 & $\begin{array}{l}- \\
7.0436 \\
1\end{array}$ & $\begin{array}{l}113 . .923 \\
2199\end{array}$ & $\begin{array}{l}1.5 \mathrm{k} \\
\mathrm{m}\end{array}$ & -49 & $1 \mathrm{~s}$ & $0 \mathrm{~ms}$ \\
\end{tabular}




\begin{tabular}{|c|c|c|c|c|c|c|c|}
\hline $\begin{array}{l}00 \\
2\end{array}$ & $\begin{array}{l}15.0 \\
3.40\end{array}$ & $\begin{array}{l}- \\
7.0371 \\
341 \\
\end{array}$ & $\begin{array}{l}113.910 \\
4658\end{array}$ & $\begin{array}{l}3.1 \mathrm{k} \\
\mathrm{m}\end{array}$ & -54 & $1 \mathrm{~s}$ & $\begin{array}{l}100 \\
\mathrm{~ms}\end{array}$ \\
\hline $\begin{array}{l}00 \\
1\end{array}$ & $\begin{array}{l}15.0 \\
6.13\end{array}$ & $\begin{array}{l}- \\
7.0336 \\
86 \\
\end{array}$ & $\begin{array}{l}113.907 \\
752\end{array}$ & $\begin{array}{l}3.9 \mathrm{k} \\
\mathrm{m}\end{array}$ & -60 & $1 \mathrm{~s}$ & $\begin{array}{l}200 \\
\mathrm{~ms}\end{array}$ \\
\hline $\begin{array}{l}00 \\
2\end{array}$ & $\begin{array}{l}15.1 \\
0.30\end{array}$ & $\begin{array}{l}- \\
7.0553 \\
12\end{array}$ & $\begin{array}{l}113.909 \\
723\end{array}$ & $\begin{array}{l}4.4 \mathrm{k} \\
\mathrm{m}\end{array}$ & -62 & $1 \mathrm{~s}$ & $\begin{array}{l}200 \\
\mathrm{~ms}\end{array}$ \\
\hline $\begin{array}{l}00 \\
1\end{array}$ & $\begin{array}{l}15.1 \\
4.50\end{array}$ & $\begin{array}{l}- \\
7.00 * \\
\% 8 \\
\end{array}$ & $\begin{array}{l}113.09 \$ \\
\# @ 27\end{array}$ & $\begin{array}{l}5.7 \mathrm{k} \\
\mathrm{m}\end{array}$ & -61 & $1 \mathrm{~s}$ & $\begin{array}{l}200 \\
\mathrm{~ms}\end{array}$ \\
\hline $\begin{array}{l}00 \\
2\end{array}$ & $\begin{array}{l}15.1 \\
7.08\end{array}$ & $\begin{array}{l}- \\
7.033 .- \\
\# 9\end{array}$ & $\begin{array}{l}\text { 113.9- } \\
@ \#) \$ 2\end{array}$ & $\begin{array}{l}6.9 \mathrm{k} \\
\mathrm{m}\end{array}$ & -62 & $1 \mathrm{~s}$ & $\begin{array}{l}500 \\
\mathrm{~ms}\end{array}$ \\
\hline $\begin{array}{l}00 \\
1\end{array}$ & $\begin{array}{l}14.2 \\
0.57\end{array}$ & $\begin{array}{l}- \\
7.050+ \\
@ ! \# \\
\end{array}$ & $\begin{array}{l}113.09 \$ \\
\text { \#@7 }\end{array}$ & $\begin{array}{l}8.1 \mathrm{k} \\
\mathrm{m}\end{array}$ & -62 & $1 \mathrm{~s}$ & $\begin{array}{l}500 \\
\mathrm{~ms}\end{array}$ \\
\hline $\begin{array}{l}00 \\
2\end{array}$ & $\begin{array}{l}14.2 \\
5.01\end{array}$ & $\begin{array}{l}- \\
7.05)^{*} \\
\& \# @\end{array}$ & $\begin{array}{l}113.9 \% \# \\
* 3\end{array}$ & $\begin{array}{l}10.3 \\
\mathrm{~km}\end{array}$ & -61 & $1 \mathrm{~s}$ & $\begin{array}{l}500 \\
\mathrm{~ms}\end{array}$ \\
\hline
\end{tabular}

$5.7 \mathrm{~km}$ dengan RSSI rata-rata -48 - (-53) dan latency baru terjadi di jarak $6.9 \mathrm{~km}$. Untuk selanjutnya 2 node aktif, jarak transmisi yang dapat diterima sejauh $4.4 \mathrm{~km}$ dengan RSSI rata-rata -54-(62) dan latency terjadi di jarak $3,1 \mathrm{~km}$ namun kecil, latency mulai membesar di jarak $6.9 \mathrm{~km}$. Selanjutnya yang terakhir 3 node aktif, jarak transmisi yang dapat diterima sejauh $4.4 \mathrm{~km}$. Ini sama dengan ketika 2 node aktif, namun perbedaan yang signifikan terletak di besar RSSI serta latency nya. Untuk RSSI rata-rata sebesar -80 - (-150) dan latency cenderung lebih besar daripada kedua kondisi yang pertama. Latency terjadi sejak jarak $0 \mathrm{~km}$ namun kecil, dan membesar di jarak $6.9 \mathrm{~km}$. Dari ketiga data tersebut dapat disimpulkan jika semakin bertambahnya node yang mentransmisikan data maka latency dan RSSI akan semakin besar. Hal ini dikarenakan ketiga node mengirimkan data kepada gateway yang sama.

Tabel VI. Data hasil receive dengan 3 node

\begin{tabular}{|c|c|c|c|c|c|c|c|}
\hline $\begin{array}{l}\mathrm{I} \\
\mathrm{D}\end{array}$ & $\begin{array}{l}\text { Wakt } \\
\mathrm{u}\end{array}$ & $\begin{array}{l}\text { Latitud } \\
\mathrm{e}\end{array}$ & $\begin{array}{l}\text { Longitu } \\
\text { de }\end{array}$ & $\begin{array}{l}\text { Jara } \\
\mathrm{k}\end{array}$ & $\begin{array}{l}\text { RS } \\
\text { SI }\end{array}$ & $\begin{array}{l}\text { Del } \\
\text { ay }\end{array}$ & $\begin{array}{l}\text { Late } \\
\text { ncy }\end{array}$ \\
\hline $\begin{array}{l}0 \\
0 \\
3 \\
\end{array}$ & $\begin{array}{l}14.53 \\
.20\end{array}$ & $\begin{array}{l}- \\
7.0487 \\
62\end{array}$ & $\begin{array}{l}113.934 \\
385\end{array}$ & $0 \mathrm{~m}$ & -64 & $1 \mathrm{~s}$ & $\begin{array}{l}50 \mathrm{~m} \\
\mathrm{~s}\end{array}$ \\
\hline $\begin{array}{l}0 \\
0 \\
2\end{array}$ & $\begin{array}{l}14.56 \\
.50\end{array}$ & $\begin{array}{l}- \\
7.0469 \\
967\end{array}$ & $\begin{array}{l}113.930 \\
0747\end{array}$ & $\begin{array}{l}800 \\
m\end{array}$ & -60 & $1 \mathrm{~s}$ & $\begin{array}{l}50 \mathrm{~m} \\
\mathrm{~s}\end{array}$ \\
\hline $\begin{array}{l}0 \\
0 \\
3 \\
\end{array}$ & $\begin{array}{l}14.59 \\
.10\end{array}$ & $\begin{array}{l}- \\
7.0436 \\
2199\end{array}$ & $\begin{array}{l}113 . .92 \\
3277\end{array}$ & $\begin{array}{l}1.5 \mathrm{k} \\
\mathrm{m}\end{array}$ & -62 & $1 \mathrm{~s}$ & $\begin{array}{l}50 \mathrm{~m} \\
\mathrm{~s}\end{array}$ \\
\hline $\begin{array}{l}0 \\
0 \\
2\end{array}$ & $\begin{array}{l}15.03 \\
.40\end{array}$ & $\begin{array}{l}- \\
7.0371 \\
341\end{array}$ & $\begin{array}{l}113.910 \\
4658\end{array}$ & $\begin{array}{l}3.1 \mathrm{k} \\
\mathrm{m}\end{array}$ & -68 & $1 \mathrm{~s}$ & $\begin{array}{l}100 \\
\mathrm{~ms}\end{array}$ \\
\hline $\begin{array}{l}0 \\
0 \\
1 \\
\end{array}$ & $\begin{array}{l}15.06 \\
.13\end{array}$ & $\begin{array}{l}- \\
7.0336 \\
86 \\
\end{array}$ & $\begin{array}{l}113.907 \\
752\end{array}$ & $\begin{array}{l}3.9 \mathrm{k} \\
\mathrm{m}\end{array}$ & $\begin{array}{l}- \\
10 \\
0\end{array}$ & $1 \mathrm{~s}$ & $\begin{array}{l}500 \\
\mathrm{~ms}\end{array}$ \\
\hline $\begin{array}{l}0 \\
0 \\
2\end{array}$ & $\begin{array}{l}15.10 \\
.30\end{array}$ & $\begin{array}{l}- \\
7.0553 \\
12\end{array}$ & $\begin{array}{l}113.909 \\
723\end{array}$ & $\begin{array}{l}4.4 \mathrm{k} \\
\mathrm{m}\end{array}$ & $\begin{array}{l}- \\
12 \\
0\end{array}$ & $1 \mathrm{~s}$ & $\begin{array}{l}200 \\
\mathrm{~ms}\end{array}$ \\
\hline $\begin{array}{l}0 \\
0 \\
1\end{array}$ & $\begin{array}{l}15.14 \\
.50\end{array}$ & $\begin{array}{l} \\
7.0509 \\
38\end{array}$ & $\begin{array}{l}113.099 \\
827\end{array}$ & $\begin{array}{l}5.7 \mathrm{k} \\
\mathrm{m}\end{array}$ & -90 & $1 \mathrm{~s}$ & $\begin{array}{l}500 \\
\mathrm{~ms}\end{array}$ \\
\hline $\begin{array}{l}0 \\
0 \\
2\end{array}$ & $\begin{array}{l}15.17 \\
.08\end{array}$ & $\begin{array}{l}- \\
7.033 .- \\
\# 9\end{array}$ & $\begin{array}{l}113.9- \\
@ \#) \$ 2\end{array}$ & $\begin{array}{l}6.9 \mathrm{k} \\
\mathrm{m}\end{array}$ & $\begin{array}{l}- \\
12 \\
0\end{array}$ & $1 \mathrm{~s}$ & $\begin{array}{l}500 \\
\mathrm{~ms}\end{array}$ \\
\hline $\begin{array}{l}0 \\
0 \\
1 \\
\end{array}$ & $\begin{array}{l}14.20 \\
.57\end{array}$ & $\begin{array}{l}- \\
7.050+ \\
@ \text { !\# }\end{array}$ & $\begin{array}{l}\text { 113.09\$ } \\
\# @ 7\end{array}$ & $\begin{array}{l}8.1 \mathrm{k} \\
\mathrm{m}\end{array}$ & $\begin{array}{l}- \\
15 \\
0 \\
\end{array}$ & $1 \mathrm{~s}$ & $\begin{array}{l}1000 \\
\mathrm{~ms}\end{array}$ \\
\hline $\begin{array}{l}0 \\
0 \\
2\end{array}$ & $\begin{array}{l}14.25 \\
.01\end{array}$ & $\begin{array}{l} \\
7.05)^{*} \\
\& \# @\end{array}$ & $\begin{array}{l}113.9 \% \\
\# * 3\end{array}$ & $\begin{array}{l}10.3 \\
\mathrm{~km}\end{array}$ & $\begin{array}{l} \\
20 \\
0\end{array}$ & $1 \mathrm{~s}$ & $\begin{array}{l}1000 \\
\mathrm{~ms}\end{array}$ \\
\hline
\end{tabular}

\section{Pengujian Aplikasi}

Pengujian kali ini dilakukan untuk menguji apakah software yang telah dibuat telah berjalan sebagaimana mestinya atau tidak. Ada beberapa skema aplikasi yang perlu di uji coba diantara lain yaitu : menampilkan marker, perubahan warna marker, serta pengiriman himbauan langsung dari maps berupa sms.

1. Menampilkan gambae pada Maps

a) Kirimkan data ke google cloud firebase

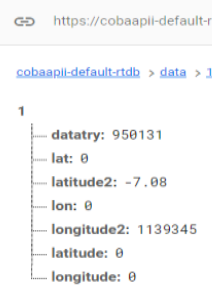

Gambar 5. Tampilan Firebase

b) Parsing data dari cloud menggunakan REST API lalu implementasikan di php

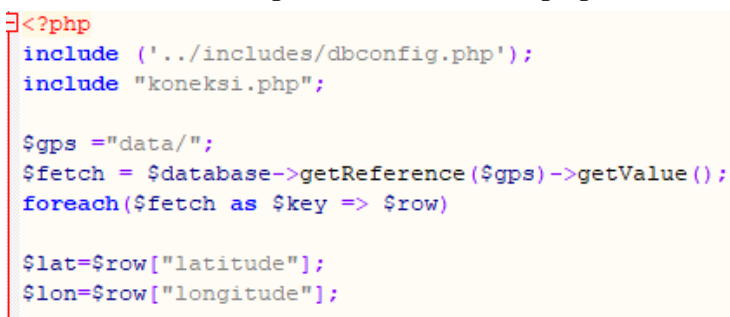

Gambar 6. Code parse data dari Firebase menggunakan REST API

\section{c) Implementasikan data yang telah di parse ke}

merupakan data rekam dari 3 kondisi yang berbeda. Yang pertama node 1 aktif, node 2 dan 3 nonaktif, yang kedua node 1, 2 aktif dan node 3 nonaktif serta yang ketiga semua node aktif. Dalam kondisi aktif semua node mengirimkan data bersamaan dan diterima oleh gateway lalu dikrimkan ke cloud secara bersamaan. Dari ketiga hasil tersebut terlihat ketika hanya node 1 yang aktif, jarak transmisi yang dapat di terima sejauh dalam maps

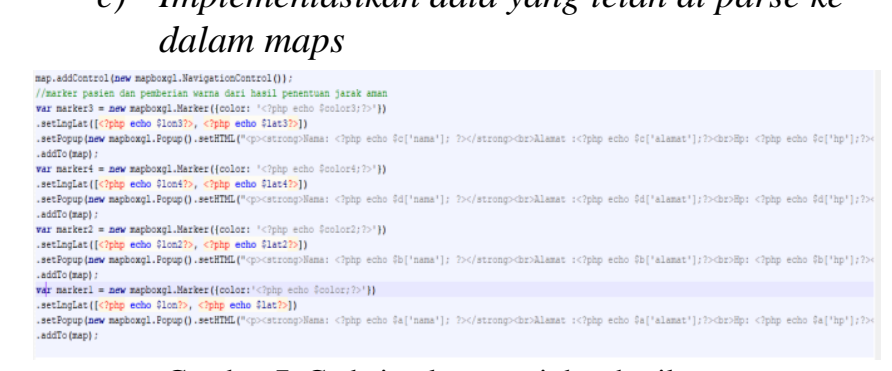

Gambar 7. Code implementasi data hasil parse 
d) Tentukan warna marker berdasarkan kategori $O D P, P D P$.

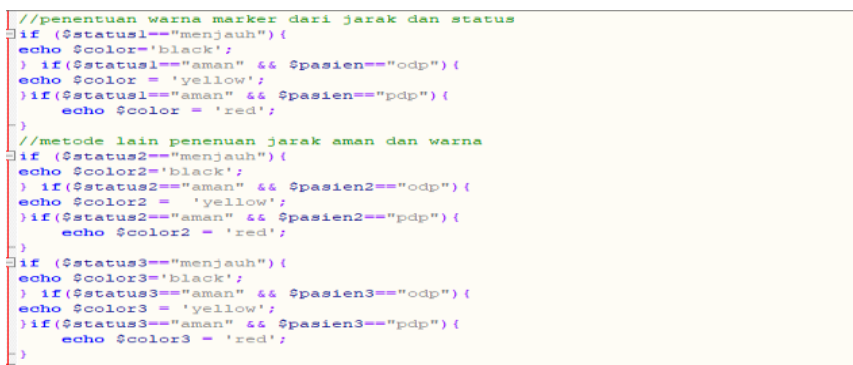

Gambar 8. Code penentuan warna marker

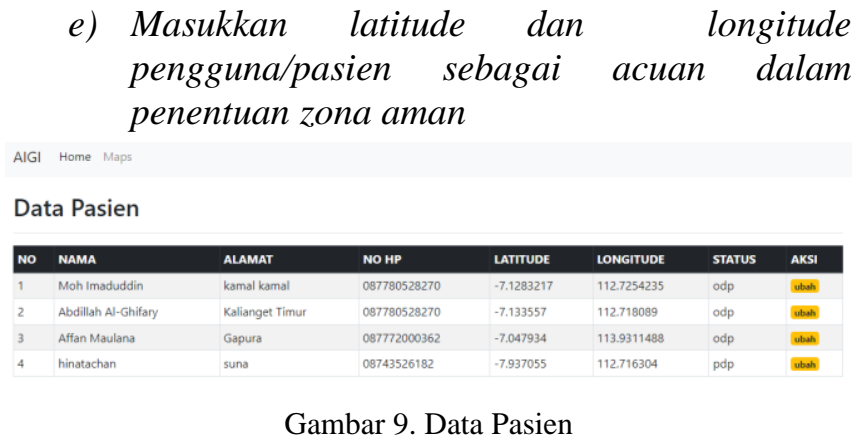

V. KESIMPULAN

Hal-hal yang dapat disimpulkan dalam penelitian kali ini ialah :

1. LoRaWAN dapat menjadi alternatif teknologi IoT baru terutama di daerah perkotaan ataupun pedesaan yang minim akan sinyal internet ataupun seluler.

2. Dengan teknologi LoRaWAN pemakaian bandwidth diantara semua node disamakan, ini bertujuan agar data yang dikirimkan dapat disampaikan secara bersamaan ke gateway.

3. Penelitian ini menggunakan Gateway dengan spesifikasi ketinggian -+ $7 \mathrm{~m}$ diatas permukaan tanah, frekuensi $923 \mathrm{MHz}$ dengan modul LoRa sx1276. Dengan 3 node mentransmit data secara bersamaan gateway ini mampu menerima jarak optimal kurang lebih sejauh 4 kilometer. Dengan RSSI terbesar di kisaran -200.

4. Node yang digunakan untuk mentransmisikan data menggunakan wemos d1 mini sebagai mikro utama, gps neo 6 serta sx1276. Sedangkan baterai yang digunakan bertipe Li-Po 3.7v $200 \mathrm{mAH}$.

5. Hasil pengujian cloud menggunakan google cloud firebase, firebase dapat menerima data realtime dengan baik dan akurat. Serta mempunya fitur filter karakter-karakter selain angka dan string.

6. Mapbox API digunakan sebagai interface maps menggunakan aplikasi web, untuk fitur-fitur yang digunakan antara lain marker, warna marker, pencarian, dialog box dan zoom out, zoo in.

7. Selain API Mapbox penelitian ini juga menggunakan API dari Firebase yang digunakan untuk memparsing data dari realtime firebase serta API dari covid19.mathro.id sebagai pemantauan perkembangan covid secara realtime di indonesia.
8. Metode heversine digunakan untuk mengkalkulasi jarak antara 2 buah titik kordinat yang berbeda. Hal ini digunakan untuk mengindentifikasi jika terjadi pelanggaran zona aman isolasi mandiri. Heversine digunakan karena memiliki selisih yang relatif kecil dengan jarak aslinya yaitu sekitar $2-3$ meter.

9. PHP merupakan bahasa pemrograman beckend yang paling banyak digunakan dalam penelitian ini.

10.QOS (Quality of Service) sangat terpengaruh oleh jarak node dalam mentransmisikan data dan jumlah node yang mentrasnmisikan data.

\section{DAFTAR PUSTAKa}

[1] R. Angriawan and N. Anugraha, "Sistem Pelacak Lokasi Sapi dengan Sistem Komunikasi LoRa," Inspir. J. Teknol. Inf. dan Komun., vol. 9, no. 1, p. 33, 2019, doi: 10.35585/inspir.v9i1.2494.

[2] W. P. Putra, R. I. M, A. Sumarudin, and A. E. Putro, "Implementasi Lorawan Server Untuk Sistem Tracking Perahu Nelayan Berbasis MQTT Protocol," J. Appl. Informatics Comput., vol. 2, no. 2, pp. 4650, 2018, doi: 10.30871/jaic.v2i2.1024.

[3] A. Augustin, J. Yi, T. Clausen, and W. M. Townsley, "A study of Lora: Long range \& low power networks for the internet of things," Sensors (Switzerland), vol. 16, no. 9, pp. 1-18, 2016, doi: 10.3390/s16091466.

[4] P. Devi, D. Istianti, S. Y. Prawiro, N. Bogi, A. Karna, and I. A. Nursafa, "Analisis Performansi Teknologi Akses LPWAN LoRa Antares Untuk Komunikasi Data End Node," Citee 2019, pp. 22-26, 2019.

[5] E. D. Widianto, A. A. Faizal, D. Eridani, R. D. O. Augustinus, and M. S. Pakpahan, "Simple LoRa Protocol: Protokol Komunikasi LoRa Untuk Sistem Pemantauan Multisensor," TELKA - Telekomun. Elektron. Komputasi dan Kontrol, vol. 5, no. 2, pp. 83-92, 2019, doi: 10.15575/telka.v5n2.83-92.

[6] J. Chen, K. Hu, Q. Wang, Y. Sun, Z. Shi, and S. He, "Narrowband Internet of Things: Implementations and Applications," IEEE Internet Things J., vol. 4, no. 6, pp. 2309-2314, 2017, doi: 10.1109/JIOT.2017.2764475.

[7] E. Winarno, W. Hadikurniawati, and R. N. Rosso, "Location based service for presence system using haversine method," Proc. - 2017 Int. Conf. Innov. Creat. Inf. Technol. Comput. Intell. IoT, ICITech 2017, vol. 2018-Janua, pp. 1-4, 2018, doi: 10.1109/INNOCIT.2017.8319153.

[8] J. A. D. M. Bastos, L. M. Afonso, and C. S. De Souza, "Metacommunication between programmers through an application programming interface: A semiotic analysis of date and time APIs," Proc. IEEE Symp. Vis. Lang. Human-Centric Comput. VL/HCC, vol. 2017-October, pp. 213-221, 2017, doi: 10.1109/VLHCC.2017.8103470. 